\title{
Isolation of Facultative Methanol-utilizing Bacteria Which Produce Electrophoretically Different Methanol Dehydrogenase
}

\author{
Kei YAMANAKA*1 and Keisuke MatSUMOTo*2 \\ Department of Food Science, Kagawa University, Miki-cho, Kagawa
}

Received August 29, 1977

\begin{abstract}
Bacterial strains capable of assimilating methanol as the sole source of carbon and energy have been isolated. These bacteria produced phenazine methosulfate-dependent methanol dehydrogenase (primary alcohol dehydrogenase, EC 1.1.99.8). The enzyme activity was detected in electrophoresis on polyacrylamide gels by activity staining technique. The dehydrogenase can be grouped to at least three types based on their mobility in electrophoresis: (1) enzyme which migrates toward the anode slowly, (2) enzyme which remains at the top of the gel at pH 9.3 and (3) enzyme which migrates to the anode at faster mobility. The three bacteria were selected as producers of the respective three types of dehydrogenase. They were facultative methanol-utilizing bacteria and two of them were identified, one as Pseudomonas sp. No. 2941 and the other as Pseudomonas sp. S25. Most isolated bacteria produced the first type of enzyme and several strains produced the second type of enzyme. Strain. S50 was the only strain which produced the third type of enzyme. These groupings of methanol dehydrogenase may contribute to the classification of methylotrophic bacteria.
\end{abstract}

Since Anthony and Zatman ${ }^{1)}$ first demonstrated a methanol dehydrogenase (primary alcohol dehydrogenase, EC 1.1.99.8) from Pseudomonas sp. M27 in 1964, this dehydrogenase has been found in many methanol-utilizing bacteria, e.g., Pseudomonas sp. AM1, Pseudomonas methanica, Pseudomonas extroquens, ${ }^{2)}$ Methylococcus capsulatus, ${ }^{3)}$. Pseudomonas oleovorans," Pseudomonas 1 and Pseudomonas $C^{5 \sim 7\rangle}$ This enzyme was further purified ${ }^{8 \sim 14}$ and crystalline preparations were obtained from Methylosinus sporium ${ }^{15}$ and Pseudomonas sp. No. 2941. ${ }^{163}$ A good similarity among these enzyme preparations can be demonstrated especially on their physiological properties: e.g., substrate specificity, electron acceptor and some of molecular properties. But one evident difference is their electrophoretic behavior on polyacrylamide gels.

In order to isolate active methanol-utilizing

*1 To whom reprint requests should be addressed. Present address: Institute of Applied Biochemistry, The University of Tsukuba, Sakura-mura, Niihari-gun, Ibaraki-ken 300-31, Japan.

*2 Present address: Department of Enzymology, Yakult Institute for Microbiological Research, Nishinomiya, Hyogo-ken, Japan. bacteria, we assayed primary alcohol dehydrogenase activity in crude extracts of methanolgrown cells of newly isolated bacteria. Then, the enzyme was detected after electrophoresis on polyacrylamide gels by àctivity staining technique. In this paper, the grouping of dehydrogenase is described based on electrophoretic mobility. Three methanol-utilizing bacterial strains were selected from three groups and some characteristics of these strains are discussed.

\section{MATERIALS AND METHODS}

Isolation of methanol utilizing bacteria. Methanol utilizing bacteria were isolated by the enrichment culture technique from sewage, active sludge, sediment and soil. The medium was composed of $0.26 \%$ $\left(\mathrm{NH}_{4}\right)_{2} \mathrm{SO}_{4}, 0.24 \% \quad \mathrm{KH}_{2} \mathrm{PO}_{4}, 0.56 \% \mathrm{~K}_{2} \mathrm{HPO}_{4}, 0.1 \%$ yeast extract, $0.05 \% \mathrm{MgSO}_{4} \cdot 7 \mathrm{H}_{2} \mathrm{O}$ and $1 \%$ methanol. The $\mathrm{pH}$ was adjusted to 7.0 before autoclaving. Magnesium sulfate was autoclaved separately and added to the medium. Methanol was also aseptically supplemented to the medium. Culture was made on a reciprocal shaker at $30^{\circ} \mathrm{C}$ for $3 \sim 5$ days. The organisms were isolated and purified further by alternate streaking technique on methanol-agar plates.

Preparation of cell-free extracts: Each isolated 
strain was grown on $100 \mathrm{ml}$ of methanol medium in a $500-\mathrm{ml}$ flask at a shaking rate of $120 \mathrm{rev} / \mathrm{min}$ at $30^{\circ} \mathrm{C}$ for $24 \mathrm{hr}$. The cells were harvested by centrifugation at $10,000 \times g$, washed twice and suspended in ice-cold $50 \mathrm{~mm}$ Tris- $\mathrm{HCl}$ buffer, $\mathrm{pH} 8.0$, containing $1 \mathrm{~mm}$ methanol. This was exposed for 5 10 min to ultrasonic oscillation at $20 \mathrm{kHz}$. Cell-free extracts were obtained after centrifugation at $14,800 \times g$ for $20 \mathrm{~min}$.

Enzyme assays. All spectrophotometric enzyme assays were made with a Hitachi spectrophotometer, model 139 or a Gilford recording spectrophotometer, model 240 , thermostated at $30^{\circ} \mathrm{C}$. Phenazine methosulfate-linked dehydrogenase activities were assayed at pH 9.6 according to the procedure of Anthony and Zatman $^{1)}$ with methanol, ethanol, formaldehyde, formate or methylamine as substrate. $\mathrm{NAD}^{+}$- or $\mathrm{NADP}^{+}$linked dehydrogenase activities were assayed in the assay mixture $(1.0 \mathrm{ml})$ containing $50 \mu \mathrm{mol}$ phosphate buffer, pH $8.0 ; 10 \mu$ mol substrate (methanol, formate, methylamine or ethanol) or $1 \mu \mathrm{mol}$ formaldehyde; $0.5 \mu \mathrm{mol} \mathrm{NAD}{ }^{+}$or $\mathrm{NADP}^{+}$with or without $0.5 \mu \mathrm{mol}$ GSH.* Hydroxypyruvate reductase(D-glycerate: $\mathrm{NAD}^{+}$oxidoreductase, EC 1.1.1.29) was assayed with Tris- $\mathrm{HCl}$ buffer, $\mathrm{pH} 7.5$ as described by Large and Quayle $^{17)}$ and activity was calculated after subtracting NADH oxidase activity. One unit of enzyme activity is defined as the amount of enzyme utilizing $1 \mu \mathrm{mol}$ of substrate or $\mathrm{NAD}(\mathrm{P})^{+}$or producing $1 \mu \mathrm{mol}$ of product per hr. Specific activity is defined as units per mg of protein. Protein was determined spectrophotometrically from ultraviolet absorption at 280 and $260 \mathrm{~nm}$.

Polyacrylamide gel electrophoresis. Electrophoresis was carried out on $7.5 \%$ acrylamide gels in Tris- $\mathrm{HCl}$ buffer, $\mathrm{pH} 9.4$, according to the procedure of Davis. ${ }^{18)}$ Protein was stained in $2.5 \%$ Coomasie blue in acetic acid-methanol (46: 454) for $1 \mathrm{hr}$. Dehydrogenase activity in the gels was detected and visualized by coupling with reduction of nitroblue tetrazolium chloride or with reduction of 2,6-dichlorophenol indophenol, as described in a previous paper. ${ }^{10)}$

Materials. $\mathrm{NAD}^{+}, \mathrm{NADP}^{+}$and $\mathrm{NADH}$ were purchased from Oriental Yeast Co., Osaka and $\beta$ hydroxypyruvic acid (lithium salt) was obtained from Sigma Chemicals Co., St. Louis, Mo., U.S.A.

\section{RESULTS}

\section{Detection of methanol dehydrogenase activity}

Methanol dehydrogenase activity was assayed on extracts of methanol-grown cells of

* Abbreviation used: GSH, reduced glutathione and PMS, phenazine methosulfate. newly isolated bacteria. This activity was determined from the rate of reduction of 2,6dichlorophenol indophenol. Active strains which produced relatively high levels of enzyme activity were selected. The enzyme activity from all selected strains linked directly to phenazine methosulfate and required ammonium chloride. Therefore, these activities were also demonstrated on polyacrylamide gels after electrophoresis immersing the gels with methanol, phenazine methosulfate and dye (nitroblue tetrazolium chloride or 2,6-dichlorophenol indophenol). The location of enzyme protein was easily visualized as a purple-blue band in the presence of nitroblue tetrazolium chloride or as a colorless band in deep blue stained gels in the presence of 2,6-dichlorophenol indophenol. Therefore, this dehydrogenase can be referred to the primary alcohol dehydrogenase.

\section{Electrophoretic behavior of methanol dehydro- genase}

All methanol-grown cells tested produced one band of methanol dehydrogenase by electrophoresis on polyacrylamide gels, but their mobilities were distinctly different. Majority of bacteria produced enzyme which migrated slowly into gels. This type was designated as the first type of dehydrogenase, and strain No. 2941 was selected as the representative strain of this type. The second type of enzyme

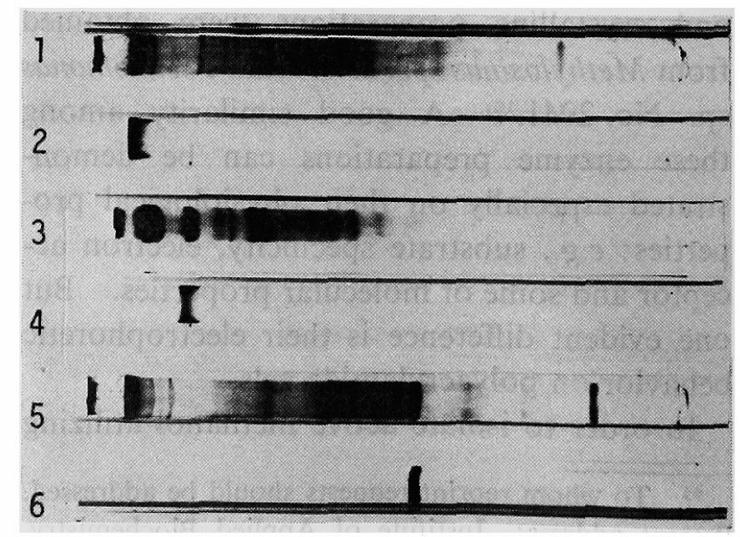

FIG. 1. Electrophoretic Pattern of Crude Extracts of Methanol-grown Cells on Polyacrylamide Gels.

1,2: strain S25; 3,4: strain No. 2941 ; 5,6: strain S50. $1,3,5:$ protein stain; $2,4,6:$ activity stain on methanol dehydrogenase. 
was characterized as not migrating into gels at $\mathrm{pH}$ 9.3. The enzyme activity remained on top of the gel during electrophoresis, while many protein bands were detected in the gel. Several strains were included in this group and strain S25 was selected as the typical strain. The third type of enzyme moved into the gel during electrophoresis. Only strain S50 showed this migration behavior.
Unlike isozyme, one enzyme band was always detected in each strain, and no bacterial strain was found to produce two or more enzyme bands. Therefore, the difference on the isoelectric point of the protein may reflect differences on migration behavior. Figure 1 shows the electrophoretic patterns of proteins and methanol dehydrogenase activities of the three selected strains, No. 2941, S25 and S50.

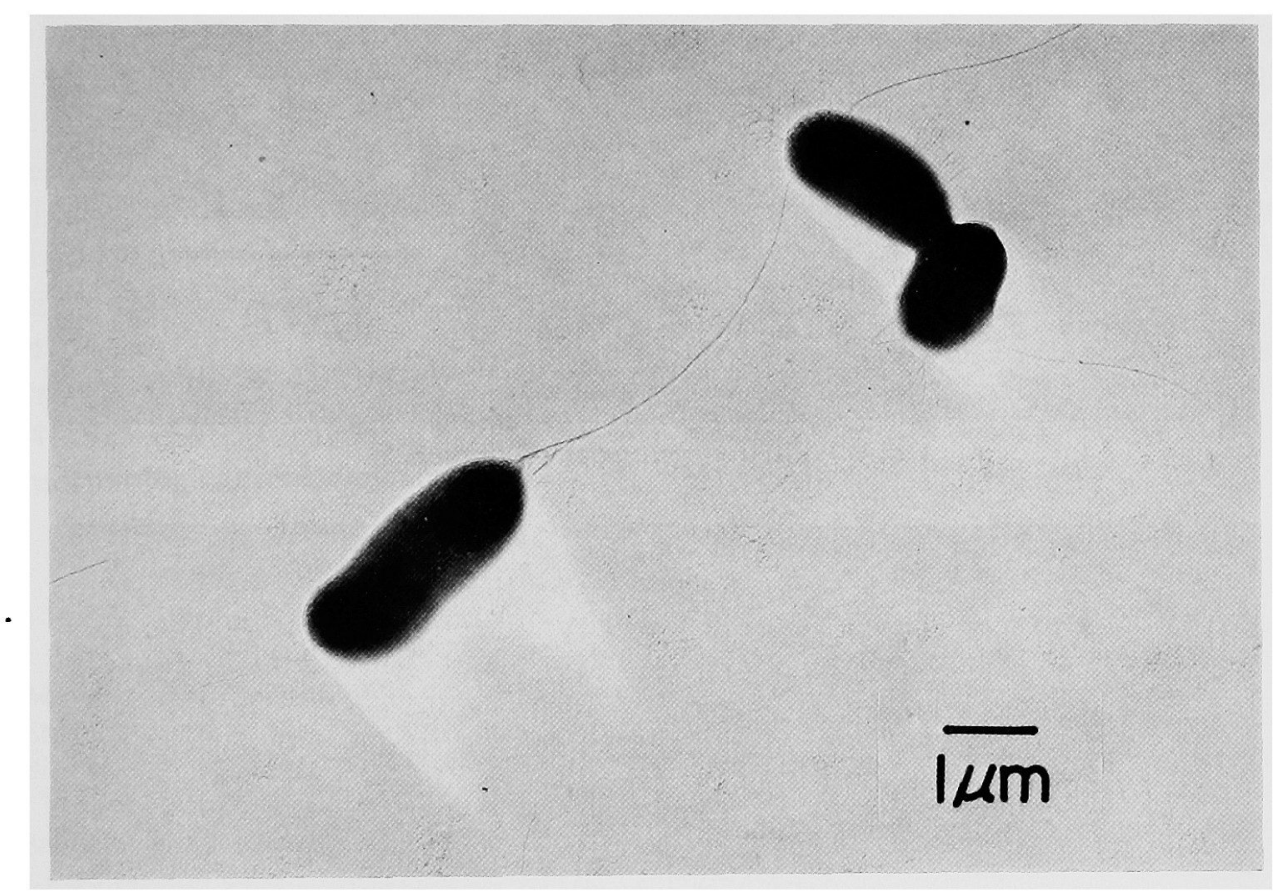

FIG. 2. Electronmicrograph of Strain No. 2941.

Table I. Specific Activities of Enzymes in Extracts of Methanol-grown Bacteria

\begin{tabular}{|c|c|c|c|}
\hline \multirow{2}{*}{ Enzymes } & \multicolumn{3}{|c|}{ Specific activity ${ }^{a}$} \\
\hline & Strain 2941 & Strain S25 & Strain S50 \\
\hline Methanol dehydrogenase (PMS) & 12.5 & 3.6 & 2.1 \\
\hline Methanol dehydrogenase $\left(\mathrm{NAD}^{+}\right)$ & 0 & 0 & 0 \\
\hline Methanol dehydrogenase $\left(\mathrm{NADP}^{+}\right)$ & 0 & 0 & 0 \\
\hline Formaldehyde dehydrogenase $\left(\mathrm{NAD}^{+}\right.$) & 0 & 0.06 & 0.08 \\
\hline Formaldehyde dehydrogenase (NAD $\left.{ }^{+}, \mathrm{GSH}\right)$ & 0 & 0.17 & 1.20 \\
\hline Formaldehyde dehydrogenase $\left(\mathrm{NADP}^{+}\right)$ & 0 & 0 & 0 \\
\hline Formaldehyde dehydrogenase (NADP $\left.{ }^{+}, \mathrm{GSH}\right)$ & 0 & 0 & 0 \\
\hline Formate dehydrogenase $\left(\mathrm{NAD}^{+}\right)$ & 0.4 & 0.4 & 6.9 \\
\hline Formate dehydrogenase $\left(\mathrm{NADP}^{+}\right)$ & 0.4 & 0.3 & 7.4 \\
\hline Methylamine dehydrogenase $\left(\mathrm{NAD}^{+}\right)$ & 0 & 0 & 0 \\
\hline Ethanol dehydrogenase $\left(\mathrm{NAD}^{+}\right)$ & 0 & 0.07 & 0.01 \\
\hline NADH oxidase & 0.04 & 0.08 & 1.58 \\
\hline Hydroxypyruvate reductase (NADH) & 11.6 & 0.03 & 6.0 \\
\hline
\end{tabular}

a Specific activity $=\mu$ moles $/ 60 \mathrm{~min} / \mathrm{mg}$ of protein. 


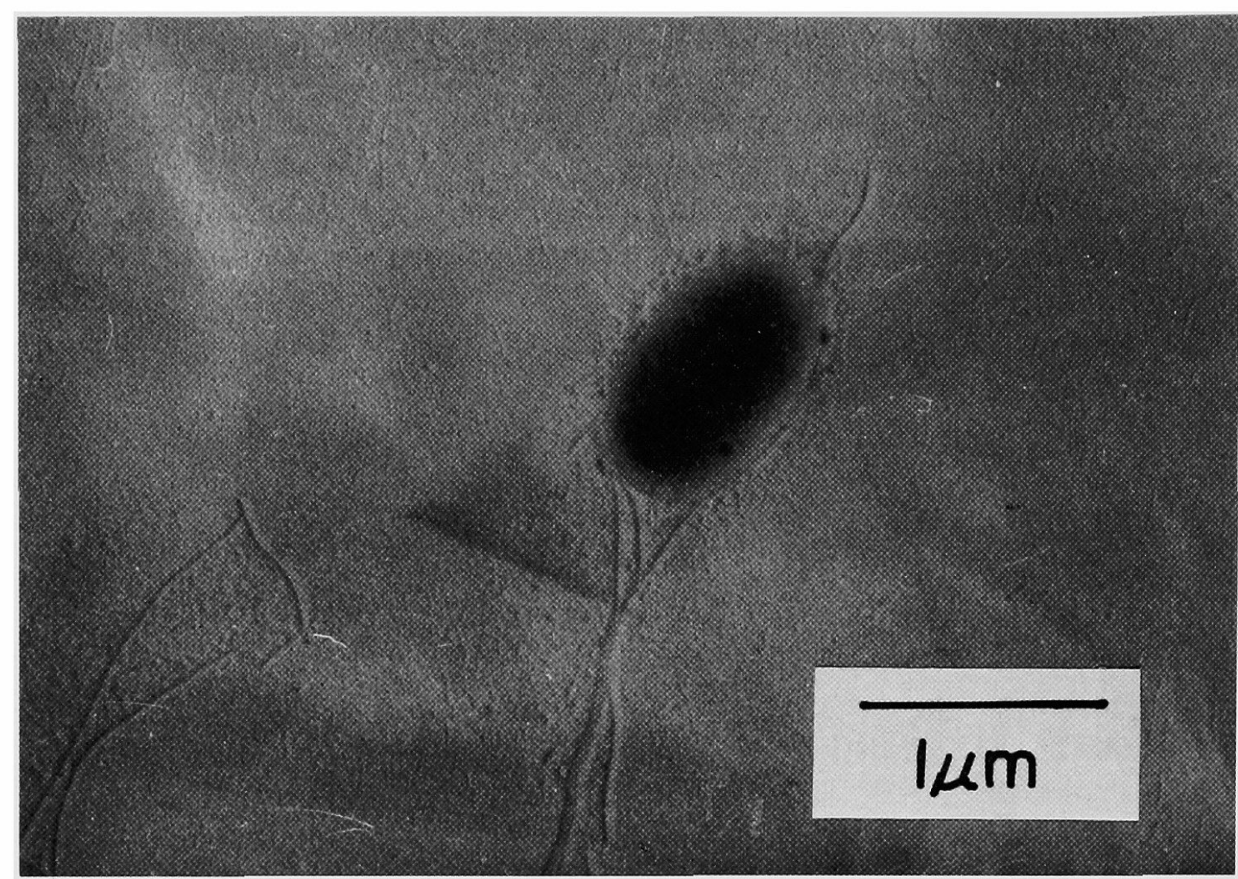

FIG. 3. Electronmicrograph of Strain S25.

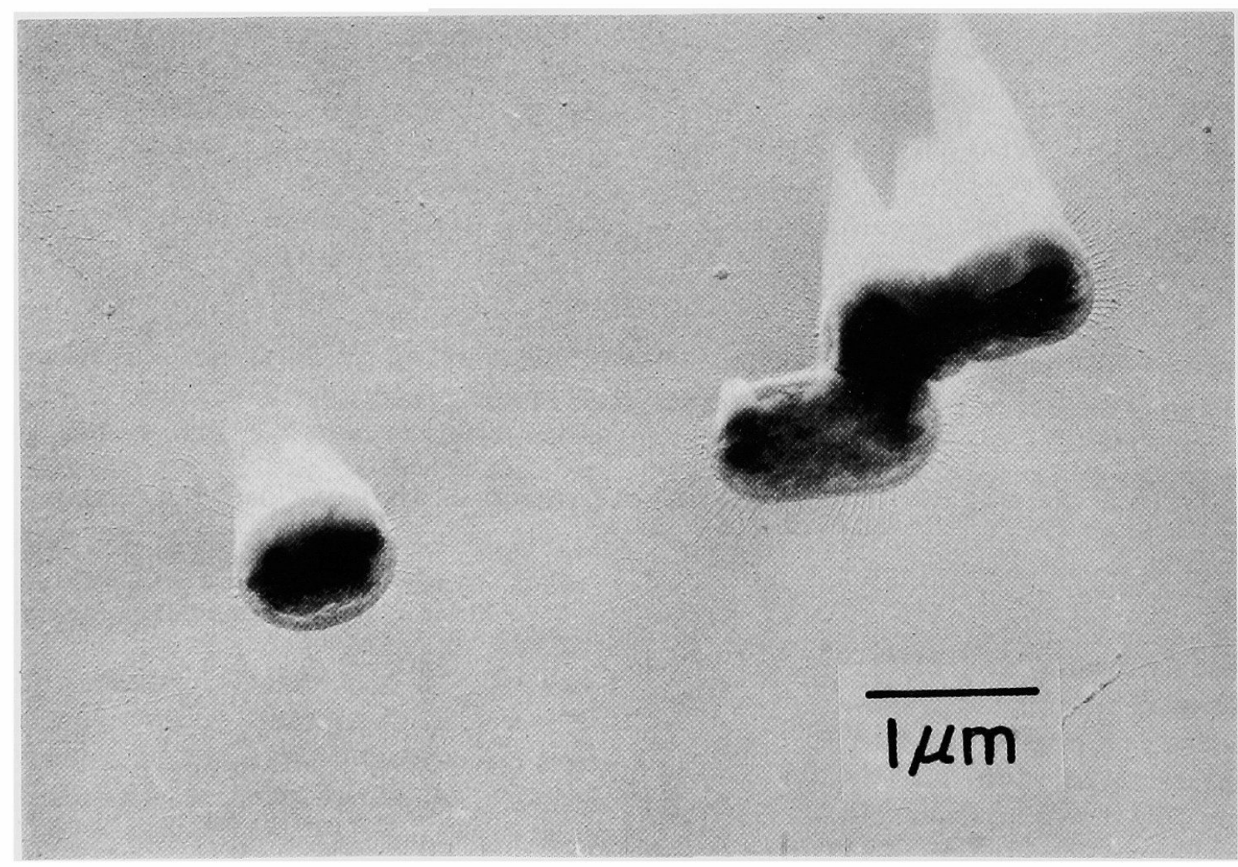

FIG. 4. Electronmicrograph of Strain S50.

Enzyme activities in extracts

Table I compared the phenazine methosulfate-linked dehydrogenase activities of the three strains in crude extracts of methanolgrown cells. Methanol dehydrogenase (prima- ry alcohol dehydrogenase) was the most active enzyme of these strains. But the activities of $\mathrm{NAD}^{+}$- or $\mathrm{NADP}^{+}$-linked methanol dehydrogenase, ethanol dehydrogenase were not demonstrated in the three organisms. The 
activity of $\mathrm{NAD}^{+}$-dependent formaldehyde dehydrogenase was demonstrated in strain $\mathrm{S} 50$, and this activity was accelerated in the presence of reduced glutathione. $\mathrm{NADP}^{+}$ could not replace $\mathrm{NAD}^{+}$. Formate dehydrogenase $\left(\mathrm{NAD}^{+}\right.$- or $\mathrm{NADP}^{+}$-linked) was also detected in strain S50, but in trace amounts in strains sp. No. 2941 and S25. This dehydrogenase activity disappeared after a short period of refrigerated storage (less than $5 \mathrm{hr}$ ). NADP ${ }^{+}$ showed the same activity for this dehydrogenase. All three organisms did not have $\mathrm{NAD}^{+}$-linked methanol and methylamine dehydrogenase activities. These results are included in Table I.

Taxonomic characteristics of the three active strains

Electronmicrographs of three strains, sp. No. 2941, S25 and S50 are shown in Figs. $2 \sim 4$. Their morphological, cultural and physiologi- cal properties were studied and summarized in Table II. Identification studies were performed by referring to the 8th Edition of Bergey's Manual of Determinative Bacterio$\operatorname{logy} .{ }^{19}$ ) All three strains are aerobic and nonspore forming Gram-negative short rods. In liquid culture, strains No. 2941 and S25 appeared mostly singly and motile with polar flagella, but strain S50 was plump rod with round ends, usually occurring in pairs or occasionally in short chains and being nonmotile. They grew well on bouillon agar and colonies were entire, smooth and circular. Strain No. 2941 produced reddish pink pigment. Two strains, S25 and S50 were noncolored, but old cultures became opaque or pale yellowish white. Table III summarized the assimilation of carbon sources by the three isolates. Methanol is apparently the most utilizable carbon source for the three strains. However, growth was not observed on for-

Table II. Taxonomical Characteristics of Three Isolated Strains

\begin{tabular}{|c|c|c|c|c|}
\hline & & 2941 & $\mathrm{~S} 25$ & S50 \\
\hline \multirow[t]{7}{*}{1.} & Morphological characteristics & & & \\
\hline & Shape & Rods & Short rods & Plump rods \\
\hline & Size & 1.0 to $1.1 \mathrm{by}$ & 0.4 to 0.7 by & 1.0 by 1.2 to \\
\hline & & 2.0 to $2.9 \mu \mathrm{m}$ & 1.1 to $1.5 \mu \mathrm{m}$ & $1.5 \mu \mathrm{m}$ \\
\hline & Motility & $\begin{array}{l}\text { Motile by polar } \\
\text { flagellum }\end{array}$ & $\begin{array}{l}\text { Motile by polar } \\
\text { flagella }\end{array}$ & Non-motile \\
\hline & Spore formation & Negative & Negative & Negative \\
\hline & Gram-stain & Negative & Negative & Negative \\
\hline \multirow[t]{19}{*}{2.} & Physiological characteristics & $\cdot$ & & \\
\hline & Growth temperature & $20 \sim 37^{\circ} \mathrm{C}$ & $25 \sim 37^{\circ} \mathrm{C}$ & $20 \sim 37^{\circ} \mathrm{C}$ \\
\hline & Growth pH & $6 \sim 8$ & $6 \sim 9$ & $6 \sim 9$ \\
\hline & Litmus milk & No changed & Alkaline & No changed \\
\hline & Nitrate reduction & Negative & Negative & Negative \\
\hline & Denitrification & Negative & Positive & Negative \\
\hline & Methyl red test & Negative & Negative & Negative \\
\hline & Voges-Proskauer test & Negative & Negative & Negative \\
\hline & Indole production & Negative & Negative & Negative \\
\hline & Hydrogen sulfide formation & Negative & Negative & Negative \\
\hline & Hydrolysis of starch & Negative & Negative & Negative \\
\hline & Liquefaction of gelatin & Negative & Positive & Negative \\
\hline & Citrate utilization & Negative & Positive & Positive \\
\hline & Urease & Positive & Positive & Negative \\
\hline & Catalase & Positive & Positive & Positive \\
\hline & Oxidase & Positive & Positive & Positive \\
\hline & Pigment production & & & \\
\hline & Pseudomonas F agar & Negative & Positive & Negative \\
\hline & Pseudomonas $\mathbf{P}$ agar & Negative & Negative & Negative \\
\hline
\end{tabular}


Table III. Growth of Three Isolates on Various Carbon Sources

$\begin{array}{lccc}\text { Carbon source } & 2941 & \text { S25 } & \text { S50 } \\ \text { Methanol } & + & + & + \\ \text { Formaldehyde } & - & - & - \\ \text { Methylamine } & + & \pm & ++ \\ \text { Dimethylamine } & - & - & + \\ \text { Trimethylamine } & - & - & + \\ \text { Ethanol } & + & ++ & + \\ n \text {-Propanol } & \pm & ++ & - \\ n \text {-Butanol } & - & + & - \\ \text { D-Glucose } & \pm & ++ & ++ \\ \text { D-Fructose } & ++ & ++ & ++ \\ \text { D-Mannose } & \pm & ++ & ++ \\ \text { D-Galactose } & \pm & ++ & ++ \\ \text { Sucrose } & \pm & ++ & ++ \\ \text { Maltose } & \pm & ++ & ++ \\ \text { D-Sorbitol } & \pm & ++ & ++ \\ \text { D-Mannitol } & \pm & ++ & ++ \\ \text { D-Xylose } & \pm & ++ & ++ \\ \text { D-Ribose } & \pm & ++ & ++ \\ \text { L-Arabinose } & \pm & ++ & + \\ \text { D-Arabinose } & \pm & ++ & - \\ \text { Glycerol } & ++ & ++ & ++ \\ \text { Glycine } & - & - & - \\ \text { Symbols denote: } & ++, \text { good growth; } & +, \text { weak } \\ \text { growth; } \pm, \text { variable; } ; & - \text { no growth. } & \end{array}$

maldehyde in batch culture. As for $\mathrm{C}_{1}$-compounds, methylamine and dimethylamine were also assimilated with different degrees of assimilation. Strain S50 assimilated trimethylamine, as well as monomethylamine. Among primary alcohols, ethanol was the second utilizable carbon source for the three strains, but $n$-propanol was assimilated by S25. Higher primary alcohols, $n$-butanol, $n$-hexanol, $n$ octanol, $n$-decanol and higher alcohols were not assimilated.

Strain No. 2941 assimilated D-fructose and glycerol, but growth was variable or weak on 11 other tested sugars. Strains S25 and S50 grew on a series of hexoses, pentoses and polyalcohols. Therefore, all three strains were facultative methylotroph. As strains No. 2941 and S25 were aerobic Gram-negative rod and motile with polar flagella, they should fall into the genus Pseudomonas. Strain S25 may correspond to Pseudomonas fuorescens type and strain No. 2941 was a typical "red methanol utilizer." Strain S50 was non-motile and had no flagellum, as shown in Fig. 4. This strain did not produce pigments and was positive in catalase and oxidase, but negative in urease. This strain can be classified as a member of group VI in Kouno's classification system of methanol utilizing bacteria. ${ }^{20}$ Further taxonomic studies will be required on strain S50.

\section{DISCUSSION}

The phenazine methosulfate-dependent methanol dehydrogenase activity is commonly demonstrable in both obligate and facultative methylotrophs and also in both assimilation pathways: serine and ribulose monophosphate. Therefore, it is the key enzyme for all types of methylotrophs. Electrophoresis of methanol dehydrogenase was reported on the partially purified preparations to determine their purity. While Methylococcus capsulatus and Pseudomonas sp. M27 were not taxonomically related, there were some similarity on biochemical and physical properties between the enzymes of two

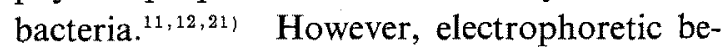
havior of two enzymes was clearly different: $M$. capsulatus enzyme moved to anode faster than Pseudomonas enzyme. Hyphomicrobium WC enzyme and Pseudomonas TP-1 enzyme migrated toward the anode at $\mathrm{pH} 8.9$, whereas Pseudomonas W1 enzyme migrated toward the cathode. $^{12}$ ) Two purified methanol dehydrogenase from soluble fraction and from solubilized fraction of Methylococcus capsulatus migrated to the anode with identical mobility in electrophoresis on polyacrylamide gels.

Comparing these results and the present study, it can be proposed that phenazine methosulfate-dependent methanol dehydrogenase can be grouped to at least three types based on electrophoretic mobility. The first type of enzyme migrates toward the anode at relative slow mobility. Enzymes from $P_{\text {seudomonas }}$ sp. M27, ${ }^{11,12)}$ Pseudomonas TP-1, ${ }^{12)}$ Hyphomicrobium WC, ${ }^{12)}$ Pseudomonas $\mathrm{C}^{14}$ and Pseudomonas sp. No. $2941^{16)}$ may belong to this group. The second type of enzyme does not migrate to the anode at $\mathrm{pH} 8.9 \sim 9.3$. Enzyme of Pseudomonas S25 belong to this 
group and Pseudomonas W1 enzyme ${ }^{12 y}$ may be included in this group. The third type is the most positively charged protein and it migrates toward the anode faster than the first type of enzyme. The isolated bacterium sp. S50 is the only strain among over 50 strains tested which produces this type of enzyme. The enzyme from Methylococcus capsulatus may be classified into this group. ${ }^{11,12)}$ All three methanol dehydrogenases from Pseudomonas sp. No. 2941, Pseudomonas S25 and a strain S50 were purified and crystallized. ${ }^{16,22)}$ Properties of these crystalline enzymes will be published in detail later. The classification of methanol dehydrogenase may contribute to establishing the classification system for methylotrophic bacteria.

\section{REFERENCES}

1) C. Anthony and L. J. Zatman, Biochem. J., 92, 614 (1964).

2) P. A. Johnson and J. R. Quayle, ibid., 93, 281 (1964).

3) R. N. Patel and D.S. Hoare, J. Bacteriol., 107, 187 (1971).

4) N. V. Loginova and Yu. A. Trotsenko, Microbiologia, 46, 210 (1977).

5) A. Ben-Bassat and I. Goldberg, Biochim. Biophys. Acta, 497, 586 (1977).

6) B. Stieglit and R. I. Mateles, J. Bacteriol., 114, 390 (1973).
7) J. S. Rock, I. Goldberg, A. Ben-Bassat and R. I. Mateles, Agric. Biol. Chem., 40, 2129 (1976).

8) C. Anthony and L. J. Zatman, Biochem. J., 96, 808 (1965).

9) C. Anthony and L. J. Zatman, ibid., 104, 953 (1967).

10) C. Anthony and L. J. Zatman, ibid., 104, 960 (1967).

11) R. N. Patel, W. J. Mandy and D. S. Hoare, $J$. Bacteriol., 113, 937 (1973).

12) G. T. Sperl, H. S. Forrest and D. T. Gibson, ibid., 118, 541 (1974).

13) A. M. Wadzinski and D. W. Ribbons, ibid., 122, 1364 (1975).

14) I. Goldberg, Eur. J. Biochem., 63, 233 (1976).

15) R. N. Patel and A. Felix, J. Bacteriol., 128, 413 (1976).

16) K. Yamanaka and K. Matsumoto, Agric. Biol. Chem., 41, 467 (1977).

17) P. J. Large and J. R. Quayle, Biochem. J., 87, 386 (1963).

18) B. J. Davis, Ann. N. Y. Acad. Sci., 121, 404 (1964).

19) "Bergey's Manual of Determinative Bacteriology," ed. by R. E. Buchanan and N. E. Gibbons, 8th ed., Williams and Wilkinson Co., 1974.

20) K. Kouno and A. Ozaki, "Microbial Growth on $\mathrm{C}_{1}$-Compounds," The Society of Fermentation Technology, Japan, 1975, p. 11.

21) R. N. Patel, H. R. Bose, W. J. Mandy and D. S. Hoare, J. Bacteriol., 110, 570 (1972).

22) K. Yamanaka and K. Matsumoto, Second International Symposium on Microbial Growth on $\mathrm{C}_{1}$-Compounds, Sept. 13, 1977 at Pushchino, U.S.S.R. 